\section{Pneumococcal Vaccine Failure in a Splenectomized Child}

\section{To the Editor:}

Severe pneumococcal disease is unusually common in splenectomized children. ${ }^{1}$ In 1977 a pneumococcal polyvalent vaccine (Pneumovax, Merck, Sharp \& Dohme) was introduced. It has been used in children at high risk from severe post-splenectomy infection. A satisfactory antibody response to the vaccine antigens has been demonstrated in children older than 2 years. ${ }^{2}$ Some studies demonstrated a weak enhancement of serum opsonic activity against pneumococcal types in older splenectomized and normal children, ${ }^{3}$ although the final test for the pneumococcal vaccine success is the clinical prevention of pneumococcal infections, in high-risk patients, and not just a serological response. Since 1978 seven patients have been reported with pneumococcal disease from a type contained in the currently used vaccine..$^{4-8}$ Five of them have been treated with chemotherapy and/or radiation. A poor antibody response has been demonstrated in patients with Hodgkin's disease vaccinated within 2 to 3 years after chemotherapy and radiation. ${ }^{5}$ Only two young patients, aged $2 \frac{1}{2}$ and 3 years with sickle cell anemia, have been reported with pneumococcal infection due to a type included in the vaccine. They had not previously received any chemotherapy or radiation. Their antibody response to vaccine was inconsistent. ${ }^{6-8}$

We have treated a 7-year-old patient with pneumococcal purulent meningitis due to a type included in the pneumococcal vaccine. She was vaccinated 30 months before the infection occurred.

\section{CASE REPORT}

GS was born in 1974. A B Thalassemia major was diagnosed at 3 months, and she had been regularly

TABLE SERUM ANTIBODY LEVELS (NG/ML) TO 5 OF 14 PNEUMOCOCCAL TYPES PRESENT IN PNEUMOCOCCAL VACCINE PNEUMOVAX

\begin{tabular}{|c|c|c|}
\hline $\begin{array}{l}\text { Type } \\
\text { Denish Classification }\end{array}$ & $\begin{array}{c}\text { Antibody Ti } \\
\text { Before Immunization }\end{array}$ & $\begin{array}{l}\text { ters (ng/ml) } \\
\text { After Immunization }\end{array}$ \\
\hline 1 & 352 & 1.748 \\
\hline 4 & 1.147 & 4.994 \\
\hline $7 F$ & 184 & 2.849 \\
\hline 8 & 216 & 3.600 \\
\hline $19 \mathrm{~F}$ & 95 & 356 \\
\hline
\end{tabular}

transfused from that time. At age 4, splenectomy was performed after signs of hypersplenism became evident. One year later she received $0.5 \mathrm{cc}$ of Pneumovax. Daily antimicrobial prophylaxis (Penicillin vs. Potassium) was started immediately after splenectomy and was not discontinued after vaccination. Serum antibody levels to five of fourteen pneumococcal types present in the vaccine, were determined before, and 3 weeks after vaccination. A satisfactory response was achieved (Table). On March 4, 1982, she was admitted in a shock-like state, after a 1-day illness. Meningeal signs were evident. The cerebrospinal fluid was unclear and the laboratory analysis provided the following values: WBC $16.200 \mathrm{~mm}^{3}$ mostly polymorphonuclears, protein $680 \mathrm{mg} / \mathrm{dl}$; glucose $26 \mathrm{mg} / \mathrm{dl}$. At gram stain, grampositive diplococcus were seen, and streptococcus pneumoniae type $12 \mathrm{~F}$, penicillin sensitive, was cultured. Blood culture was sterile. The pneumococcal type was confirmed by the World Health Organization laboratories.

She received crystalline penicillin intravenously and 5 days after treatment, some improvement was noticed. She was discharged after 2 weeks. Right abducens palsy was the only sequelae.

This report presents a double preventive treatment failure in a splenectomized patient. First, a pneumococcal vaccine failure was observed in a splenectomized child vaccinated at the age of 5 . A good antibody response was demonstrated against at least five pneumococcal types. Unfortunately type $12 \mathrm{~F}$, responsible for this patient's infection was not then tested. There was no previous chemotherapy or radiation therapy. A penicillin prophylaxis failure occurred with a subsequent penicillin sensitive pneumococcal infection. A compliance failure of prophylactic treatment cannot be absolutely excluded.

Larger clinical studies should be reported until widespread pneumococcal vaccination is justified. Until then the pneumococcal vaccination is limited to a small group of high-risk patients.

\section{REFERENCES}

1. Eraklis AJ, Filler RM: Splenectomy in childhoodA review of 1,413 cases. J Pediatr Surg 1972; 7:382-388.

2. Cowan MJ, Amman AJ, Wara DW, et al: Pneumococcal polysaccaride immunization in infants and children. Pediatrics 1978; 62:721-727.

3. Giebink GS, Foker JE, Kim Y, et al: Serum antibody and opsonic responses to vaccination with pneumococcal capsular polysaccharide in normal and splenectomized children. I Infect Dis 1980; 141:404-412.

4. Preheim L, Rytel M: Pneumococcal Infection after vaccination. Lancet $1978 ; 2: 1317$.

5. Minor DR, Schiffman G, McIntosh LS: Response of patients with Hodgkin's disease to pneumococcal vaccine. Ann Intern Med 1979; 90:887-892.

6. Ahonkhai VI, Landesman SH, Fikrig SM, et al: Failure of pneumococcal vaccine in children with sickle-cell disease. N Engl J Med 1979; 301:26-27.

7. Sumaya CV, Harbison RW, Britton HA: Pneumococcal vaccine failures. Two case reports and review. Am J Dis Child 1981; 135:155-158.

8. Overtuf GO, Field R, Edmonds R: Death from Type 6 pneumococcal septicemia in a vaccinated child with sickle cell disease. N Engl J Med 1979; 300:143.

A. Koren, $\mathrm{MD}$ Z. Efrati J. Algazi

E. Katzuni, MD

Department of Pediatrics and Bacteriology Laboratory Central Emek Hospital Afula, Israel 